\title{
総説 6
}

\section{ロボット手術の安全性}

\section{〜医療技術のテクノロジーアセスメントの考え方〜}

\section{Safety of Robot Surgery treatment \\ The View of the Technology Assessment of Medical}

\author{
田倉智之* \\ 東京女子医科大学大学院先端生命医科学研究所先端工学外科学分野
}

\section{Takura Tomoyuki}

Institute of advanced Biomedical Engineering \& Science, Graduate school of Medicine, Tokyo Women's Medical University

\begin{abstract}
Surgery domain is considered to be most a domain to be argued with respect to medical safety. Especially Robot Surgery should be involved the technology error which originates in operation in addition to the conventional human error, it is complex and a possibility that the high risk of uncertainty will be puffed up is hidden. When performing mitigation of a risk, and examination of prevention, it is necessary to set the target of examination as the beginning. Furthermore, it becomes important the procedure of the target achievement. Robot Surgery also needs to clarify importance which the correlation between risk and risk. In addition, since the shortage of mastery by the side of the user who is one of the risk factors means the fall of the capability concerning curtailment of the risk factor which mechanical structure and IT function have, it is considered to be indispensable to development of a future Robot Surgery from the result of risk assessment to improve an educational training program and a guideline.
\end{abstract}

Key words

Robot Surgery, Technology assessment, Safety of medical, Treatment benefit, Treatment risk.

\section{1.はじめに 〜安全とは不確実性へのチャレンジ〜}

医療は，社会システムの基本要素である“人間” に対する科学的な探求行為に依っており, 経済およ び倫理，法制度等を包含した社会の縮図ともいえ， 科学技術の進展の与える影響が比較的高い分野であ る.このため医療システムの本質は, 生命および健 康における“不確実性・不確定要素”に対し, 日及

**東京女子医科大学

₹ 162-8666 東京都新宿区河田町 8-1
イノベーションを進める医療技術を用いていかに効 率的かつ適正（有効に）に対応を行ない社会的な認 知（インフォームドコンセントを含む）を得るか, ということにあるといえる。医療分野における医学 教育および診断・治療行為（診療プロトコールや医 療アウトカムの評価), 医療経済（医療機関経営，医 療保険制度), さらに社会保障システム（年金，社会 援護等）は，す心゙てこの “不確実性・不確定要素” への対応方法を基本理念に検討されるべきであり, 現在も漠然としながらこの理念に基づいたシステム が構築されてきていると考えられる.

特に医療現場に打ける各種診断は，この“不確実 性”の軽減が一つの目的にあると考えられ, 各種治 


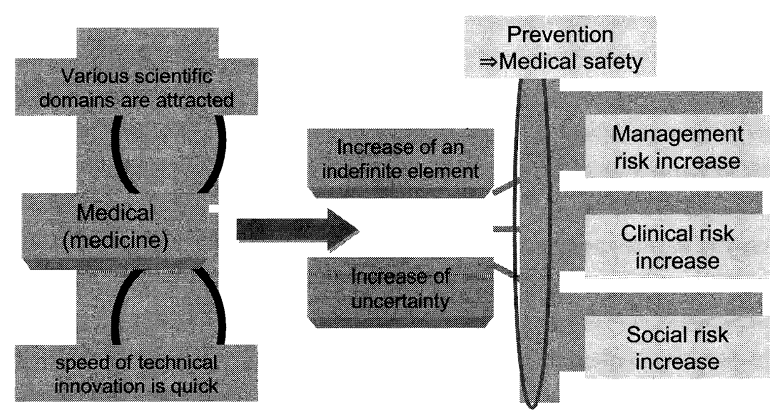

Fig. 1 増大する医療の不確実性

療はこの “不確定要素” の除外が目的の一部にある とも言える。これらの考え方は, 近年,「医療の安全」 という概念で医療現場に浸透しつつあり，科学的な 議論が進められてきている。この「医療の安全」は, 臨床学上の有効性 (生存率, 社会復帰率, 患者 $\mathrm{QOL}$ 等）と経済学上の有用性（費用対効用，医療機関経 営等）のバランスの上に成り立つ“医療の結果（医 療アウトカム)” の上位概念に位置づけられ, 生命の 安全, 健康の安全等の身体 (物理) 的な価值のみな らず，受療上の不安（苦痛等）および受療満足等の 精神的な価值や, 医療サービス提供側の負担（治療 リスクに対する身体的・精神的負担, 医療訴訟上の 費用的な負担等）の軽減を含めた広い概念と考えら れる (Fig. 1).

\section{2. 手術とロボット 〜リスクを数多く包含する手術領域〜}

医療サービスのリスクにおいて, 処置・手術領域 は, 外部環境（患者や外部者の理解, 監視) から最 も遠いと考えられる。また，エラーの存在が機能回 復不可能な合併症を引き起こす可能性が高く, 最悪 の場合生命にまで影響を及ぼすケースまでみられる ため, 医療安全に係わる議論が最も必要な領域と考 えられる。このことについては, 重篤な医療事故（医 療過誤）に関する医療事故調査会等の統計の中でも 処置・手術領域におけるケースが大多数を占める結 果となっている点からも裏付けられる注1) (Fig. 2). 特に，手術領域においては，「医療知識・技術の未熟 性・独善性」や「チーム医療の未熟性・意思の疎通 性が低い」を要因として, “脳外科” “産科” “整形外 科”領域で顕著な事例が散見している. なお, 医療 安全に関心が高まり, 医療事故の概念も定着しつつ ある状況であるとは言え, 顕在化していない事故や

注 1）医療事故調查会（京都新聞. 2003.06.19 朝刊）等

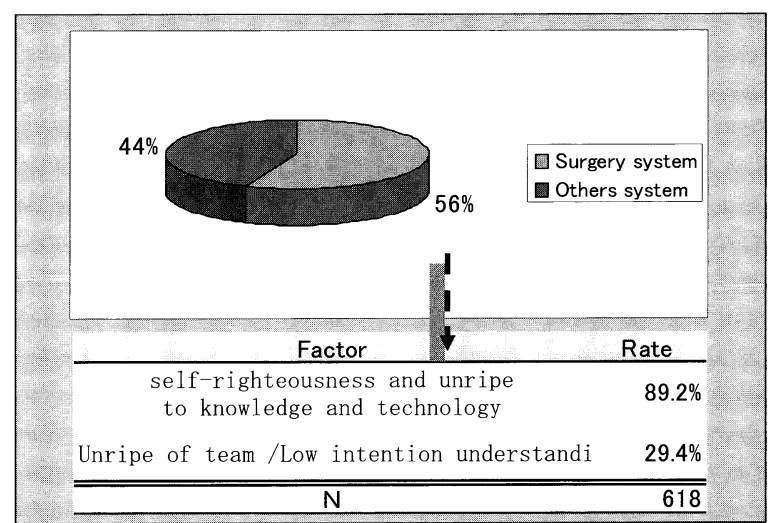

Fig. 2 手術領域の医療事故の概況

ハインリッヒの法則でいらところのハザード （hazard）の量については充分に明らかにされていな いことに留意が必要である.

一方，この手術分野は，今後，マイクロ・サージ エリー, ロボット・サージェリー等の新たな精密工 学システム・IT システムの導入が進むことは必至で あり, 従来のヒューマン・エラー以外にもオペレー ションに起因するテクノロジー・エラーを絡めた複 合的で不確実性の高いリスクが増長する可能性を秘 めている，以上から，処置・手術領域においては， 顕在需要および潜在需要への対応を適切に進めるた めにも，フールプルーフやフェイルセイフ等の工学 的なシステムの研究開発を促進する意義は非常に高 いと推察される.

\section{3. リスクの考え方}

\section{〜ベネフィットの概念が必須〜}

手術療法等の医療技術の安全性の構築は, 医療サ 一ビスの提供に伴う不利益の回避や低減を目的とす ると考えられる。その検討のためには，医療におけ る有害事象（リスク）という概念について整理を行 なら必要がある。このリスクについては，製造や金 融, 運輸等の産業では古くから議論され, ある程度 成熟された対応システムが完成されており現在も 日々進歩している。医療分野における安全向上の検 討においては，まずこのような他分野の先進事例に 学ぶべきであるが，医療の特性に配慮した独自の発 展も必要と考えられる, なお, リスクとは, 単に「危 険」という意味に捉えられがちであるが，本来の意 味は「予想との乘離」を指すものである.そのため, リスクの軽減や予防の検討を行なう場合, 最初に検 討の目標（goal）を設定（予想の構築を）すること 


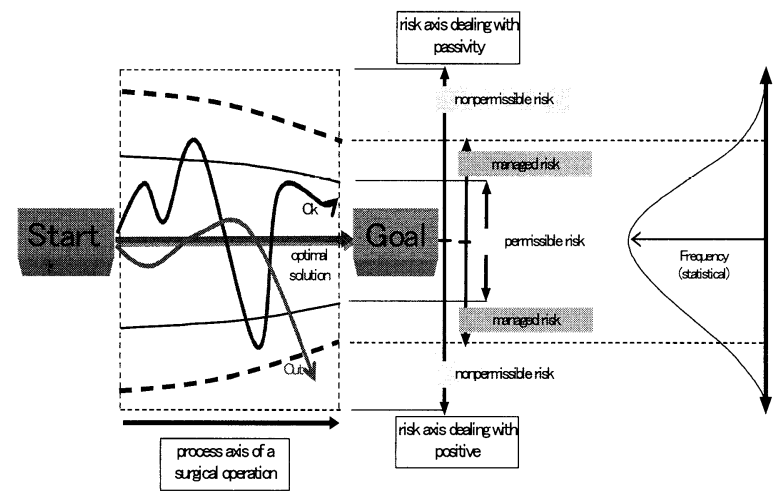

Fig. 3 手術時のリスク管理（目標設定）の考え方

が必要となり, その目標達成の手順（process）の精 査が重要となる. 以上から，リスクに係わる本質的 な議論は，最初の目標設定がポイントといえる（Fig. 3).

手術療法の場合，この目標設定はある疾患（patient needs）への対応，すなわち治療を目的達成手段とし て得られた治癒結果（outcam）となる。このアウト カムは, 手術療法の適用の結果として患者が得る結 果であり，その中には健康や社会生活に対して得ら れる利点（treatment benefit）と健康や社会生活に生 じる損失（treatment risk）を内包していると考えるべ きである.また，リスクを管理するリスク管理（risk management）とは，目標設定に対してベネフィット とリスクのバランスを管理してゴールに至る手段 (ツ 一ル）といえる. よって, 手術療法の安全性の向上, すなわち手術リスクの検討で重要となる目標の設定 には, リスクの指標のみならずベネフィットの指標 も必要となる訳で, リスクの概念だけでは議論は成 り立たないと考えられる。要は, 手術療法における 手術リスクとは, ベネフィットに対する相対的な位 置づけにあるものであり,「benefit vs Risk」の概念の 中で検討されるべきものである点に留意が必要であ る（Fig. 4). なお, 個別のリスクに関する議論, 例 えば, 受容リスクや残存リス等のリスク評価（risk assessment）およびリスク低減のデザインや ISO (International Organization for Standardization, 12100 • 14121）等の各種規格, 環境条件やインフラの整備の 議論は, このような上位概念の整理が行なわれてさ らに価值が増してくるものと考えられる.

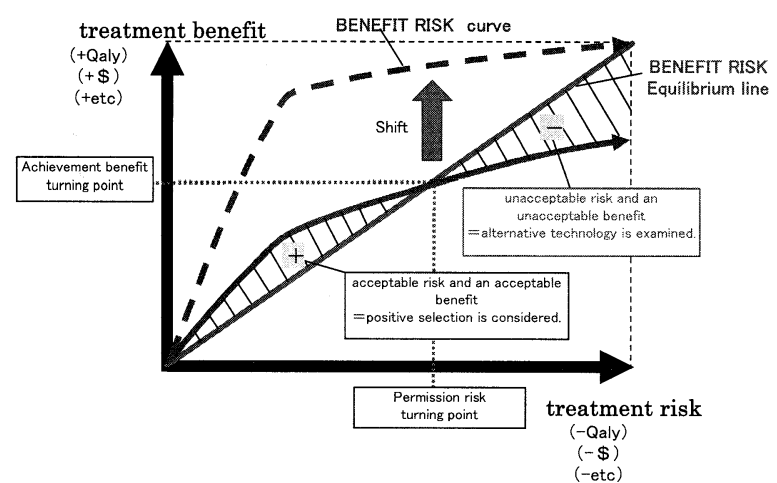

Fig. 4 手術の BENEFIT RISK 曲線（手技選択時の判断指 標)

\section{4. 安全性向上のためのリスク掌握 〜リスクの構造分析〜}

手術療法の安全性向上を目的に, リスクを軽減す るための医療機器・処置器具等の設計やリスクの発 生を未然に予防するためのシステム整備（専門医の 育成や環境整備含む）を推進するには，各手技の特 性に応じたリスクの構造を掌握すること必須である。 また，リスクを定量的に表現し議論を進めることも 重要である. 従来の安全対策は, リスクが及ぼす最 終的な影響, すなわち, ある有害事象が患者の健康 に与える影響等のエンドポイントにおけるアウトカ ムの議論が充分なされておらず, 表面的な対策が多 かったと考えられる. 今後は, 科学的な技術評価 (technology assessment）の手法に基づき，医師の経 験值や行動則および患者への最終的な影響を計量分 析していくことが必要である。そのためには，各リ スク間の相互関係 ${ }^{1223)}$ とリスク個々が有する重大性 （weight）を明らかにする必要がある（Fig. 5)。

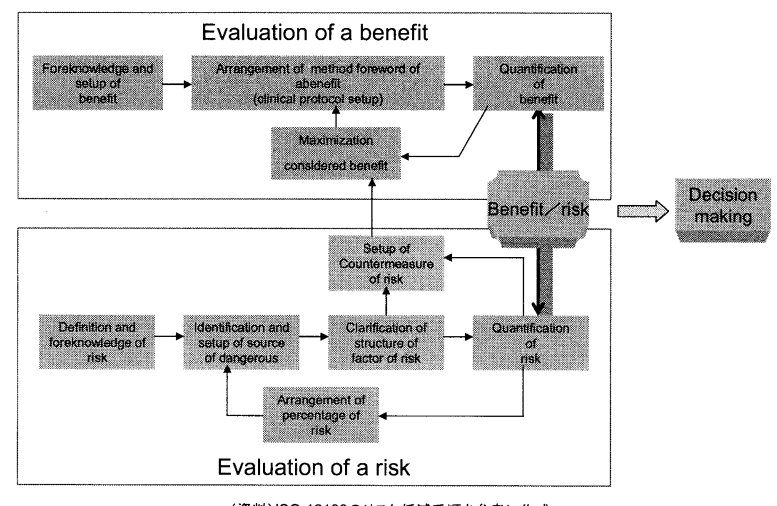

Fig. 5 手術におけるリスク対策の進め方 


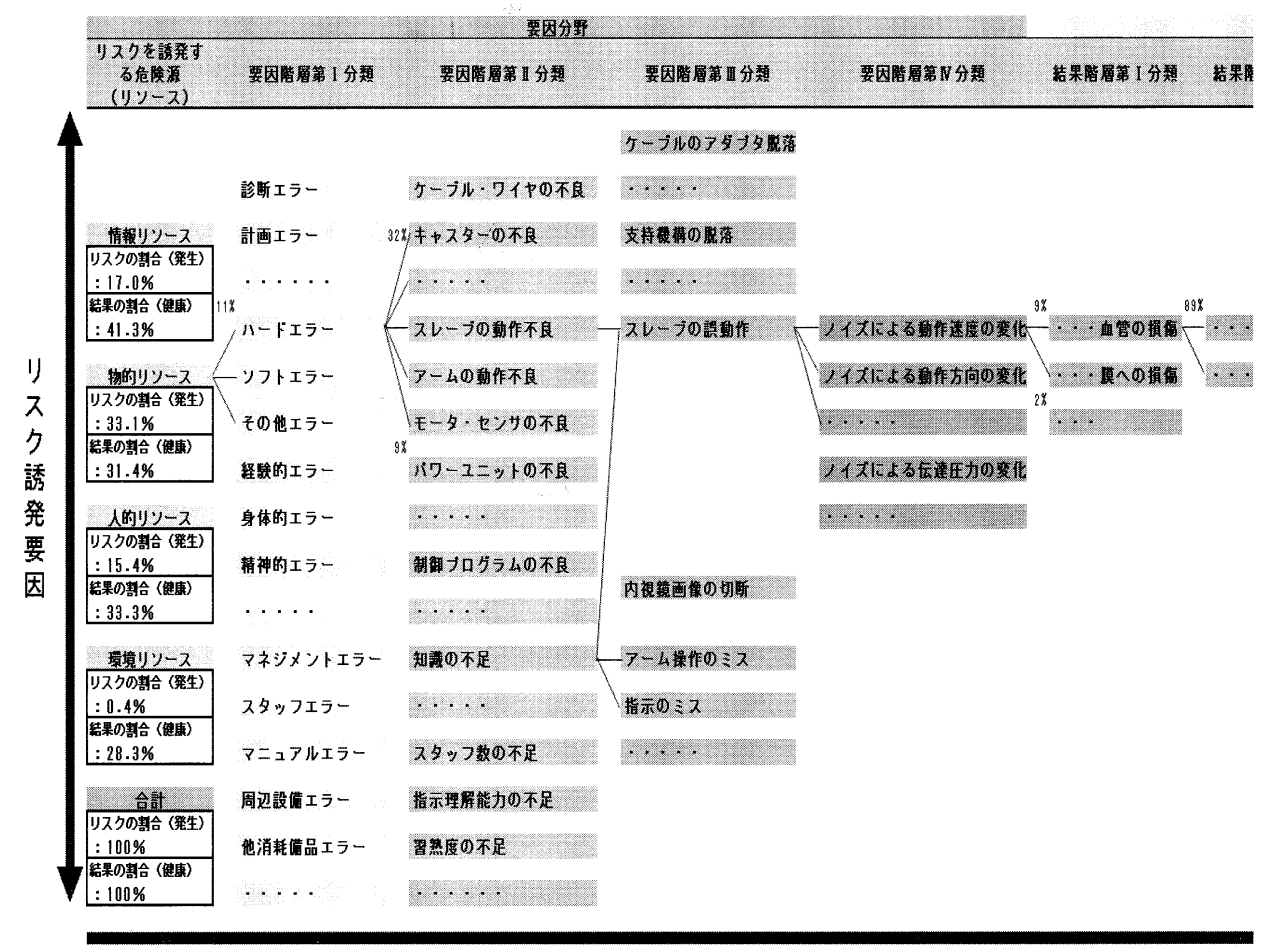

エラーこ長構造 : エラーが增大するプロセス
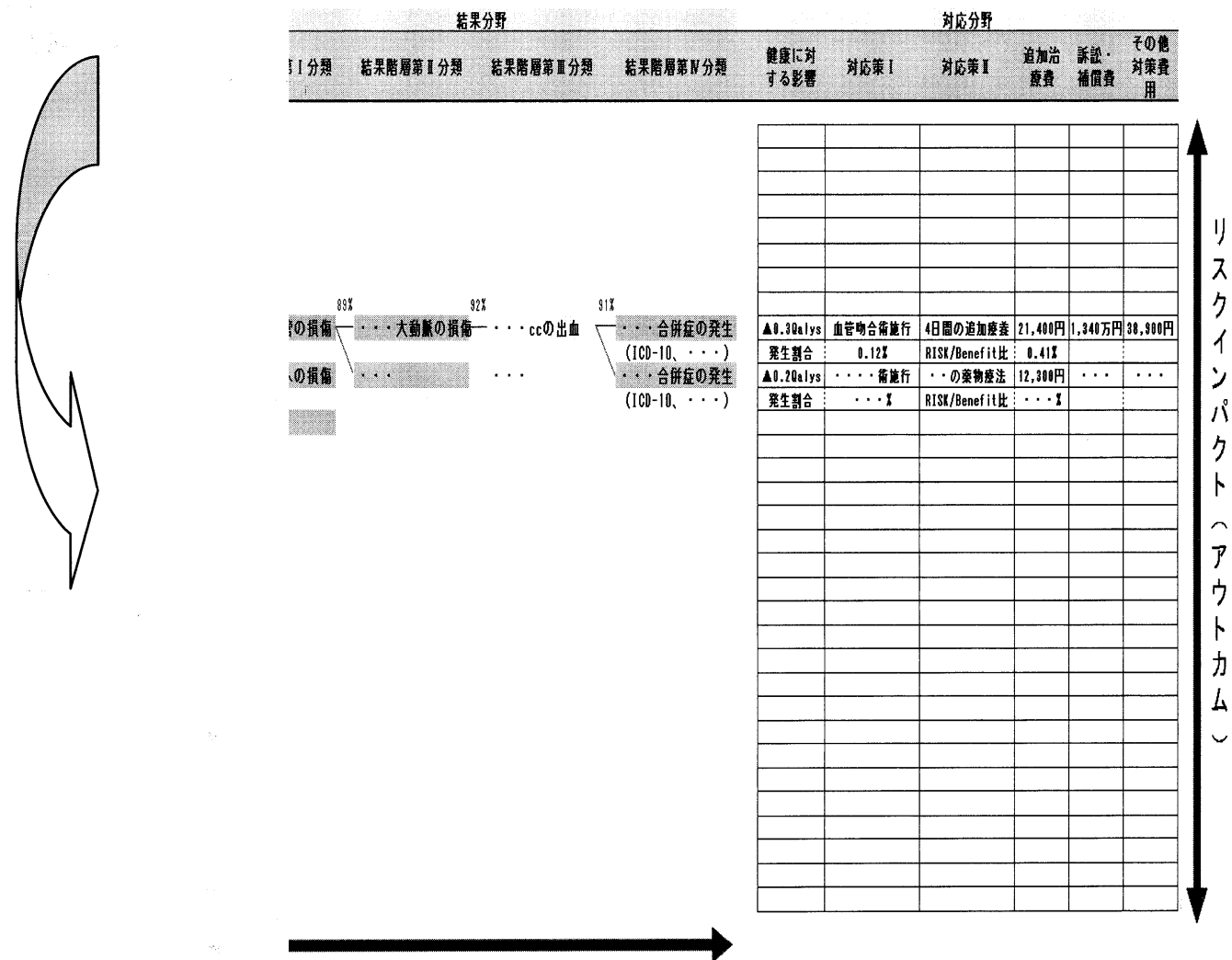

Fig. 6 RS のリスク定量化のプロセス（イメージ） 


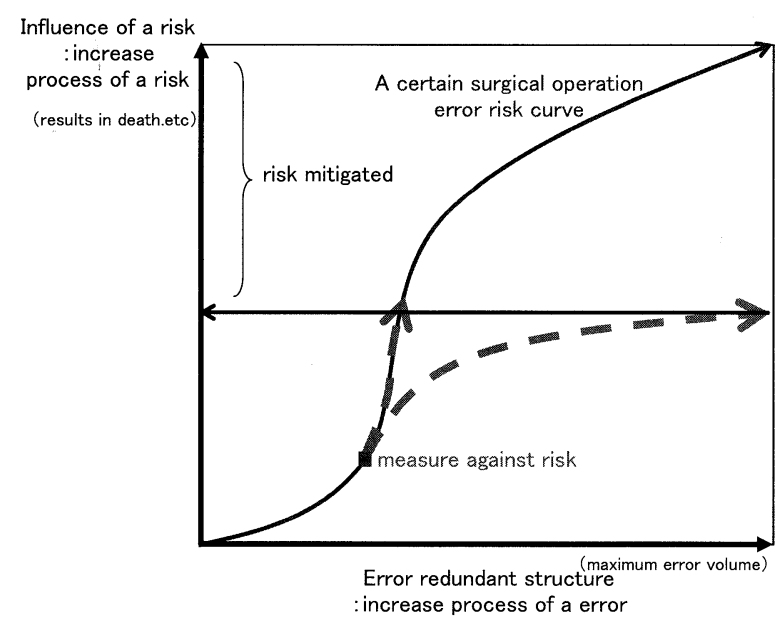

Fig. 7 手術におけるエラーとリスクの関係

リスクの構造を検討するにあたり，リスクを誘発 する危険源（リソース）の同定や与条件の整理吕前 もって必要となる。ロボット手術（Robot Surgery 以 下 RS とする）の場合は，工学技術を中心とした「物 的リソース」, 術者の能力等を中心とした「人的リソ 一ス」，その他運用体制等を中心とした「環境リソー ス」が基本的なリスク管理対象として挙げられる. その他, 患者側の疾患ニーズ等の不確定要素もリス ク管理対象と考えられ，これは術前の確定診断や手 術計画等の範疇として「情報リソース」として整理 する. 物的リソースは, 従来の手技との比較といら 意味でRSにおける最も特異なテーマと考えられ， この特異性が「人的リソース」,「環境リソース」,「情 報リソース」にどのような影響を与えるのかという 視点でリスクの検討を進めると, RS 特有のリスクの 議論が明確となり，ひいては的確な安全対策の検討 に繋がると考えられる，得られたリスクアセスメン トの結果は, 全体に占める各リスク要素の発生割合 と関係するリスクインパクト（健康に対する影響や 生じるコスト）の割合を整理し，特に影響の大きい リスク要因（key risk）の除外を中心に安全対策を推 進することが肝要である（Fig. 6).

リスクは，エラー㔯長（表面から細部へ）が進む につれて指数関数的に増加するもののある時点まで 進むと, リスクの量は大きく変化しなくなると考え られる。要は, 重篤な有害事象が顕在化してしまう と選択できる対応策が少なくなると同じである，安 全性の向上には，その前段階でリスクの連鎖を断ち 切ることが重要である (Fig. 7).

\section{5. おわりに \\ 〜人的なリソースを中心に安全対策を〜}

RS は，アウトカムに占める工学的な領域の干渉の 余地が他の手技に比べて高いと考えられる. 特に, リスクの要因として機械的な構造や IT 機能に起因し たものが多く想定される。しかし，それら以外にも RS に対する術者の理解不足や経験不足, または運用 体制自体の未成熟等の存在が挙げられる。この使用 者側の習熟不足が拡がると, 工学的なアプローチで は解決されない残存リスクの評価や新たなデバック・ アイデアの提供が充分に行なわれないため, リスク 要因の削減に必要な能力低下が進み, RS の安全対策 が推進されなくなることが懸念される。そこで，今 後の RSの発展には, リスクアセスメントの結果か ら明らかとなった人的リソース面の課題等に基づき, 教育研修プログラムの開発や使用条件のガイドライ ンを策定していくことが必須と考えられる.

\section{文献}

1) 津本周作.データマイニング技術の臨床応用. 特集, 最新医学 2003; 58(8): 1864-1870.

2) 松岡貴美子ほか. 医療データマイニングによるインシ デントデータ解析 (No. 2). 医療と検機器・試薬 2002; 25(4): 275-285.

3) Kuo WJ, et al. Data mining with decision trees for diagnosis of breast tumor in medical ultrasonic images. Breast Cancer Res Treat 2001; 66: 51-57. 